\title{
FIDEICOMMISSUM SUBSTITUTION IN THE CIVIL CODE REGULATION AND ITS PRACTICAL USE
}

\section{CARMEN TEODORA POPA}

\section{Carmen Teodora Popa}

Faculty of Law, Department of Law

University of Oradea, Oradea, Romania

Corespondence: Carmen Teodora Popa, University of Oradea, General Magheru St. Oradea,

Romania

E-mail: bnppopacarmen@gmail.com

\begin{abstract}
:
This paper aims to analyze the fideicomission substitution in light of the change in the New Civil Code in this field and its use in practice. Analyzing the current regulation in the matter of the institution of fideicomission substitution, predominantly French, one can see a change in the legislator's optic in relation to the old regulation where such a legal operation was forbidden. From the point of view of practitioners, however, we have found that they call too little or no such institution.

KEYWORDS: FIDEICOMISSION SUBSTITUTION, LIBERALITY, TESTAMENT, ESTABLISHED, DISPOSE
\end{abstract}

\section{SHORT HISTORY}

The origin of the fideicomission substitution can be said to be the Roman law where there were two operations that can be considered as precursors to the current fideicomission substitution $^{1}$ substitution and fideicomisis. The substitution of heirs consists of a provision whereby the disposer designates another person to take the place of the established heir, when the latter would not have collected the inheritance. In Roman law there were several forms of substitution: vulgar, pupil, quasi-pupil or exemplaris ${ }^{2}$.

Vulgar or habitual substitution is identified with that of the current regulation and is a provision contained in a will by which a second legatee is appointed by the agent to receive the property or goods as a subsidiary if the first legatee does not they might or would not want to receive them.

Pupil substitution consists in appointing a person who would come to the inheritance instead of the institution if the latter would have died before puberty.

Quasi-pupil substitution is the provision that allowed the parents of the family to choose an heir to the child who, due to his state of mind, was unable to be tested ${ }^{3}$.

The Fideicomis was a provision contained in a testament that provided a gratification request to preserve and transmit the good received to a second gratificated ${ }^{4}$.

\footnotetext{
${ }^{1}$ J. Kocsis, P. Vasilescu, Drept civil. Succesiuni, [Civil law. Succession ], Editura Hamangiu, București, 2016, p.189.

${ }^{2}$ A.N. Gheorghe, Manual de drept succesoral,[ Manual of succession law] Editura Hamangiu, București, 2013, p.130.

${ }^{3}$ Fr. Deak, R. Popescu, Tratat de drept succesoral, [Inheritance law]vol. II, Moștenirea testamentară, Editura Universul juridic, București, 2014, p. 219.
} 
In the feudal law, the fideicomission substitution had an important role because it ensures for nobility the intact preservation of wealth, with the obligation to transmit it from generation to generation ${ }^{5}$.

The institution of fideicomission substitution was also regulated in the Romanian law (Andronache Donici Code, Calimach Code and Caragea Code), being used until the entry into force of the Civil Code from $1864^{6}$. Following the model of the Napoleonic Civil Code, the Romanian legislator forbade fideicomission substitution until the current regulation was adopted.

If in the old regulation the fideicomission substitution was forbidden, being hit by absolute nullity, the new regulation allows in certain cases the fideicomission substitution.

\section{CONCEPT AND REGULATION}

At present, the fideicomisic substitution is regulated in the Fourth Book on Inheritance and Liberties, Title III "Liberalities", Chapter I, Section 3, "Substitutions, fideicomisis", art. 993-1000 Civil Code.

Substitution can be defined as the provision of a liberal (donation or tied), permitted by law, whereby the one who disposes obliges the donor or legatee, called the institution, to administer the goods received and to transfer them at his death to another person, called substitute, also designated by the dispatcher. For example, disponing person A (the trustee) leaves a property for B (set up or strike), with the obligation for B to administer the property, not to alienate it and transfer it to $\mathrm{C}$ (the substituted) at his death, which was appointed by dispatcher A.

By broad law, fideicomission substitution was qualified in doctrine as a modo-based liberality made $a b$ initio in favor of the institution ${ }^{7}$. The pregnancy pushes on his shoulders, and the pregnant woman is the substitute.

The purpose of recognizing the validity of the fideicomission substitution by the legislator is to protect and preserve some family goods and the possibility that these goods may reach generations to grandchildren, great grandchildren ${ }^{8}$.

The French doctrine defines the fideicomission substitution as the disposition by which the dispositor commits the gratification with the task of preserving during his lifetime the goods that are donated or transmitted to him by binding and to transmit, upon his death, to a second person also established by the person who makes the dispositions ${ }^{9}$.

\footnotetext{
${ }^{4}$ M.D. Bocșan, Testamentul. Evoluția succesiunii testamentare in dreptul roman, [ The Will. The evolution of the testamentary succession in Roman law] Editura Lumina Lex, București, 2000, p.66.

${ }^{5}$ M.M. Soreață, Noutăți legislative în materia succesiunilor introduse prin Noul Cod civil, [Legislative News on Succession Issues Introduced by the New Civil Code] Editura Hamangiu, București, 2013, p. 80;

6 The 1864 civil code defines the fideicomission substitution, which it prohibited in all cases in art. 803 as follows: Substitutions or fideicomes are prohibited; any provisions by which the donor, erede or the liaison will be entrusted to conserve and hand over to a third person shall be null, even with respect to the donor, the appointed hereditary or the legatee.

${ }^{7}$ J. Kocsis, P. Vasilescu, op.cit, p.192.

${ }^{8}$ I.Popa, Drept civil. Moșteniri și liberalități, [Civil law. Heritage and liberties], Editura Universul juridic, București, 2013, p.404.

${ }^{9}$ F. Terre, Y. Lequette, S. Gaudemet, Droit civil. Les successions. Les Liberalites, ed. A patra, Ed. Dalooz, Paris, 2013, p.538, citat după I. Popa, Fiducia și substituția fideicomisară, două instituții care nu și-au justificat
} 
According to art. 993 The Civil Code, the provision by which a person, called the appointed person, is entrusted with the administration of the property or goods which are the subject of liberty and handing them over to a third party, called the substitute, appointed by the possessor, shall take effect only if permitted by the law.

\section{CONDITIONS FOR THE FIDEICOMISSION SUBSTITUTION}

\section{a) The existence of two successive liberties that have the same object to two} people

Thus, for the existence of the fideicomission substitution, the presence of two liberalities having the same object in favor of two different persons, both appointed by the disposer, liberalities to be performed successively is required. The first liberality is in favor of the institution and can take the form of donation or will. We appreciate that when substitution takes place through the will, it should be authentic, due to the complexity and the effects of this legal mechanism. This first liberality must be in compliance with the substantive and formal conditions required for donation or tied and executed at the death of the testator or at the date of the conclusion of the donation contract. The second liberality will always be mortis causa, it is made in favor of the substitute and will be executed at the death of the instituted.

The conditions of fideicomission substitution are not met if the two liberties are not successive, but they are achieved at the same time as the opening of the inheritance.

In case of fideicomission substitution, it is not about two successive transmissions, but about two liberalities that run in succession, the acquisition being unique and resulting from the person who disposes, both for the established and for the substitute.

The fideicomission substitution implies the existence of a person who dispenses and at least two successive links: the institution and the substitute. Under fideicomission substitution, the institution can only be a person and the substitute can be both a person and a legal entity ${ }^{10}$. The two recipients of the substitution, the institution and the substitute must have the necessary capacity to receive liberties.

Thus, according to art. 994 paragraph 3 Civil Code, the incapacity to dispose is appreciated in relation to the dispatcher and the ones to receive in relation to the institution and the substitute.

The fideicomission substitution may be only one, that is, a single substituent can be established, it can not be gradual when the dispenser strikes the first substitute with a substitution in favor of a second, third substituted. In this respect, Art. 996 paragraph 3. The Civil Code provides that "the substitute can not, in turn, be subject to the obligation to

(încă) utilitatea practicăa, [Fiducia and fideicomission substitution, two institutions that have not (yet) justified their practical utility ] in ,5 years the Civil Code. The Notary’s perspective”, Editura Monitorul oficial, 2016, p.96.

10 I. Genoiu, Substituțiile fideicomisare și liberalitățile reziduale în reglementarea noului Cod civil, [Substitutional substitutions and residual liberties in the regulation of the new Civil Code] in the Romanian Journal of Private Law nr.3/2012. 
administer and transfer the goods". Also, fideicomission substitution can not be eternal, that is, to benefit the descendants of the institution at infinity.

b) That the instituted be required to administer the goods received and to transmit, upon its death, to the substitute, also appointed by the possessor;

This task is stipulated in the will of the disposer or in the donation contract concluded between the dispatcher and the established.

It is the duty of the institution to administer the objects of liberty, and he has no right of disposal over them.

The obligation of the institution not to alienate and render the substitute can refer to both universality, a share of a universality (in the case of links) and a determined individual asset.

Regarding this issue, two opinions were expressed in the literature.

In a first opinion, to which we assume, the institution has no right to dispose goods, whether for a consideration or free of charge, can not alienate or strike ${ }^{11}$. Thus, the instituted one is the owner of the goods received, but its right of ownership is seriously limited, by exercising the attributes of a alieno nomine, that is, in the name and on behalf of the substituted.

The unavailability of goods in the patrimony of the institution also has consequences for its creditors. Thus, the creditors of the instituted will not be able to track the assets that are subject to fideicomission substitution.

In a second opinion, it is argued that the fideicomission substitution does not presume the unavailability of the assets in the patrimony of the instituted ${ }^{12}$. Thus, for the goods that form the subject of liberality, the substitute is the cause of the orderer and not of the institution, which means that the obligation to transmit must be understood not the obligation to transfer a right by a legal act, but only an obligation to teach a good, the right arising from the act of liberality made by the substituted.

c) The right of the substituted is born only at the death of the instituted

We are in the presence of fideicomisical substitution when the orderer establishes succession order not only for his death but also for the case of the death of the instituted. Until the death of the instituted, the substitute has no current right in respect of the objects of liberty that comprise the fideicomisical substitution, but only possible rights ${ }^{13}$.

\footnotetext{
${ }^{11}$ În acest sens, a se vedea Fr. Deak, R. Popescu, op.cit., p.233; I. Genoiu, Dreptul la moştenire în Noul Cod civil, [The right to inherit in the New Civil Code] Editura C.H.Beck, p. 257;

${ }^{12}$ D. Chirică, Tratat de drept civil. Succesiunile şi liberalitățile, [Civil law treaty. Successions and liberties Editura C.H.Beck, 2014, p. 157.

${ }^{13}$ D. Chirică, op.cit, p.167.
} 


\section{THE EFFECTS OF THE FIDEICOMISSION SUBSTITUTION}

The effects of fideocomission substitution are regulated in Art. 995-999 Civil Code.

The subject of fideicomission substitution may be any fixed, mobile or immobile, corporal or intangible, determined or determinable. The goods that form the object of liberality must be identified and exist in nature in the patrimony of the instituted person at his death.

Consequently, if, at the time of the instituted's death, either a part of the goods which formed the object of liberty covered by the charge in question or all of those goods are no longer in its possession, the substitute can not claim them. It can not be imposed on the instituted to give the substituted other goods than those which have been the subject of liberty or their equivalent in case of alienation. This consequence stems from the fact that the fideicomission substitution involves two transmissions with the same object, one in favor of the instituted and the other in the favor of the substituted, but both of the disposer's patrimony without the actual subrogation.

By way of exception, when liberty has as its object securities, the burden also affects the securities that are replacing them. It operates in this hypothesis a real substitution.

If liberty has as its object rights subject to advertising formalities, the task must be subject to the same formalities. In the case of buildings, the task is submitted to the land book.

In order to carry out the task, the person who makes the dispositions may impose on the instituted the provision of guarantees and the conclusion of insurance contracts.

If the instituted is a heir reservist of the disposer, the value of the burden will be imputed only on the available amount of the inheritance of the instituted (Art. 998 Civil Code). Consequently, by the mechanism of fideicomission substitution it is not possible to diminish the inheritance reserve that would benefit the other heirs of the instituted, which will come to the inheritance of the instituted in competition with the substituted.

The provision by which the instituted is obliged to transfer the good of the substituted during his lifetime is not a fideicomission substitution and is subject to the prohibitive provisions of art. 993 Civil Code.

The fideicomission substitution should not be confused with regular or vulgar substitution. The fideicomission substitution differs from vulgar substitution by an essential element: in case of fideicomission substitution, two or more liberalities with the same object are executed successively, at different times, while in the case of vulgar substitution, a liberality is executed in a single moment, namely at the moment of the disposer's death.

Then the fideicomission substitution presupposes, on the part of the dispositor, the determination of the succession order, establishing not only the rules of his own inheritance, but also those of the instituted. In the case of vulgar substitution, the disposer takes only a precautionary measure, assuming the first liaison can not or does not want to collect the inheritance. 


\section{THE INEFFECTIVENESS OF FIDEICOMISSION SUBSTITUTION}

According to art. 1000 Civil Code, where the substituted precedes the instituted or renounces to the benefit of liberty, the property is the property of the instituted, unless it is foreseen that the asset will be gathered by the heirs of the substituted or has been designated a second substituted.

By devoting this solution, the legislator basically recognizes the validity of a vulgar substitution, in the sense that the dispositor obliges the instituted to administer the received goods and to pass them to the substituted's death, and if he does not want or can not benefit from liberality, the orderer establishes a the second gratified to benefit from liberty.

\section{CONCLUSIONS}

In conclusion, in the case of the fideicomission substitution one can notice a radical change of the legislator's view in relation to the old regulation, where such legal mechanism was forbidden. Thus, inspired by the provisions of the French Civil Code, the New Civil Code regulates the institution of fideicomission substitution, removing it from the prohibition regime established by the Civil Code of 1864.

Nevertheless, the fideicomission substitution remains an institution rarely used in notary practice and its usefulness remains doubtful. On the part of practitioners, there is reluctance to appeal to this institution of the fideicomisial substitution to solve concrete issues. It has been proposed in the doctrine, as a solution for the salvation of this institution by the legislator, that the fideicomission substitution does not affect the inheritance reserve ${ }^{14}$.

\footnotetext{
${ }^{14}$ I. Popa, op.cit., p.113- The author points out what the attractiveness of the substitution would be in relation to a donation a grandfather would do to his nephew if the effects were the same, but the means used would be much simpler and more consolidated, that is, a classic donation contract.
} 
1. J. Kocsis, P. Vasilescu, Drept civil. Succesiuni, [Civil law. Succession ], Editura Hamangiu, București, 2016;

2. A.N. Gheorghe, Manual de drept succesoral,[ Manual of succession law] Editura Hamangiu, București, 2013;

3. Fr. Deak, R. Popescu, Tratat de drept succesoral, [Inheritance law]vol. II, Moștenirea testamentară, Editura Universul juridic, București, 2014;

4. M.D. Bocșan, Testamentul. Evoluția succesiunii testamentare în dreptul roman, [ The Will. The evolution of the testamentary succession in Roman law] Editura Lumina lex, București, 2000;

5. M.M. Soreață, Noutăți legislative în materia succesiunilor introduse prin Noul Cod civil, [Legislative News on Succession Issues Introduced by the New Civil Code] Editura Hamangiu, București, 2013;

6. I.Popa, Drept civil. Moșteniri și liberalități, [Civil law. Heritage and liberties]Editura Universul juridic, București, 2013;

7. F. Terre, Y. Lequette, S. Gaudemet, Droit civil. Les successions. Les Liberalites, ed. A patra, Ed. Dalooz, Paris, 2013, p.538, citat după I. Popa, Fiducia şi substituţia fideicomisară, două instituții care nu și-au justificat (încă) utilitatea practică, [Fiducia and fideicomission substitution, two institutions that have not (yet) justified their practical utility ] in 5 years the Civil Code. The Notary's perspective, Editura Monitorul oficial, 2016;

8. Genoiu, Substituțiile fideicomisare și liberalitățile reziduale în reglementarea noului Cod civil, [Substitutional substitutions and residual liberties in the regulation of the new Civil Code] in the Romanian Journal of Private Law nr.3/2012.

9. Genoiu, Dreptul la moștenire in Noul Cod civil, [The right to inherit in the New Civil Code] Editura C.H.Beck;

10. D. Chirică, Tratat de drept civil. Succesiunile și liberalitățile, [Civil law treaty. Successions and liberties Editura C.H.Beck, 2014. 